\title{
Sorbent Mineralogy in the Most Basin and Their Utilization for Reclamation Works
}

\author{
Michal Řehoř1, Petr Vráblík², Jaroslava Vráblíková2 ${ }^{2}$ Lukáš Žižka1 \\ ${ }^{1}$ Research Institute for Brown Coal in Most, Most, Czech Republic \\ ${ }^{2}$ Department of Natural Sciences, Faculty of Environment, J. E. Purkyně University in Ústí nad Labem, Ústí nad Labem, \\ Czech Republic \\ Email:Wildova.Eliska@gmail.com
}

How to cite this paper: Řehoř, M., Vráblík, P., Vráblíková, J. and Žižka, L. (2017) Sorbent Mineralogy in the Most Basin and Their Utilization for Reclamation Works. Open Journal of Geology, 7, 1767-1773. https://doi.org/10.4236/ojg.2017.712118

Received: November 11, 2017

Accepted: December 8, 2017

Published: December 11, 2017

Copyright (C) 2017 by authors and Scientific Research Publishing Inc. This work is licensed under the Creative Commons Attribution International License (CC BY 4.0).

http://creativecommons.org/licenses/by/4.0/

\begin{abstract}
The contribution is focused on the relation between sorptive efficiency, mineral structure, and reclamation extraction of clay sorbents originating from the Most Basin. Clay sorbents are an important accessory raw material that occurs on several localities in the North Bohemian Brown Coal Basin, which are briefly described in the first part of the paper. The results from clay sorbents were obtained by mineralogy survey based on a diffract analysis with a D 5000 Siemens X-ray diffractometer. Localities, where zeolites and montmorillonites were found, are the main subjects of the research. The results show that parameters of clay sorbents mined in these localities are suitable for reclamation works. A successful reclamation with the use of bentonites is demonstrated on Strimice dump.
\end{abstract}

\section{Keywords}

Sorption, Bentonite, Geology, Restoration

\section{Introduction}

The Most Basin (formerly North Bohemian Brown Coal Basin) represents the largest supply of brown coal in the Czech Republic. The surface brown coal quarries caused considerable damage to the surrounding landscape. Rapid adaptation and step by step incorporation of these anthropogenic formations into territory's ecosystem is in the interest of both the region's inhabitants and the mining companies. Successful reclamation works require fertilization of sterile and phyto-toxic sites. Natural clayey sorbents are possible solution in this case. Clays are often used in agricultural applications, in engineering and construction applications, in environmental remediations, in geology and in many other 
miscellaneous applications [1]. Bentonite deposits are significant source of those sorbents. Bentonites have the potential to be used as a low cost sorbent since it is naturally available and has high surface area [2]. Bentonite is a naturally occurring clay with very high expansion capability (swelling capacity), high ion exchange capacity and very low permeability to water (hydraulic conductivity) [3]. The contribution describes main mined deposits at Cerný vrch by Branany and Rokle u Kadane. High-quality commercial bentonites normally contain over $80 \%$ of montmorillonite, which is expected to give various bentonite products similar sealing properties. However, the other minerals in bentonite may vary substantially within, and especially between, different quarries [4]. The article also deals with already performed bentonite application using bentonite from the Cerný vrch locality.

\section{Materials and Methods}

The geological situation of both large brown coal basins is rewiewed in this chapter in relation to the presumed occurrence of claystone sorbents. The research of the characteristics of the rocks was commenced in four current mining localities. These were the Bílina, Libous, Vrsany, and CSA mines. The characteristics of the stratigraphic situation are set out here with respect to the reclamation utility and potential occurrence of claystone sorbents. In the recultivation, there are easily usable quarter rocks in the Bilina mine area (topsoil, loess and loess loams are selectivelly mined and used as fertilizable rocks) and grey kaolinite-the illite claystone of Libkovice strata, which forms the upper horizon of tertiary [5]. The rocks of the delta sandy strata, which form the largest volume of the overburden rocks, are unusable from a reclamation perspective, and the coal claystone can be even characterised as phyto-toxic. Only the claystone of Libkovice strata has potential (with many limitations) to be used as claystone sorbents. Quarternary rocks, suitable for use in the reclamation, can also be found in the forefield of the Vrsany mine [6]. Arable topsoil and very rich and quality deposits of loess are selectively extracted and used as fertilizable rocks. But the yellow clays of overburden strata and sandy claystone of upper inter deposit is of no use in reclamations, and the coaly claystone of the lower inter deposit is practically phyto-toxic. Potential claystone sorbents cannot be found in the locality. The situation regarding the next two mining localities is more promising. In the CSA mine, a quarter is almost mucked off, and the grey claystone of top massive is, with the exception of a sideritic horizon over the head of coal seam, suitable for use in recultivations. Potential claystone sorbents cannot be found in the locality, either. Quartery arrable topsoil is quarried selectively and deposited in the Libous mine. The grey claystone of top massive is suitable for use in recultivations. The horizon of texturally heavy yellow clays on the head of tertiary is the single exception [7]. Brown montmorillonitic claystone on the upper horizon of tertiary (under yellow clays) is taken into account as potential claystone sorbents suitable for use in the reclamation. Only the montmorillonitic 
claystone of the Libous mine and perhaps-with many limitations-the brown claystone of the Libkovice strata at the Bílina mine can be used in overburden layers as claystone sorbents. A more favorable situation is in the horizon of bedrock (vulcano-dettriric strata), where more deposits of bentonite with excellent sorption qualities can be found (especially Cerný vrch and Rokle). The petrographic and mineralogic pattern of stratigraphic horizons lying in the way of the advancement of specific open pit mines in the North Bohemian Basin is dealt with in the framework of the grant task. The results from clay sorbents were obtained by mineralogy survey based on a diffract analysis with a D 5000 Siemens $\mathrm{X}$-ray diffractometer. This device can be used for identification and characterization of powders, thin films, single crystals, polycrystalline and amorphous materials, for phase identification/quantification, crystallinity determination, structure determination and refinement, and for measurements under non-ambient conditions.

\section{Results and Discussion}

\subsection{Basic Characteristics of the Potential Sorbents of the Most Basin}

A potential sorbent usable for reclamation works in the region of the North Bohemian Basin is the caolinitic-illitic claystone of the overburden Libkovice strata of the Bílina mine (limited utility), the montmorillonitic overburden claystone of the Libous mine and the bentonites of the Cerný vrch and Rokle localities. Just out of intrest, numerous deposits of zeolites in nearby Ceské Stredohorí Mountains can also be mentioned. These have great mineralogic significance, but none of them has the character of a minable locality according to contemporary economic criteria. The localities are usually active quarries, where appropriate vulcanite is the utility mineral and zeolite mining is economically impossible.

\subsubsection{Overlying Kaolinite-Illite Claystone of the Libkovice Strata of the Bílina Mine}

They form the upper horizon of the tertiary level in the Bílina mine. This rock type consists mainly of clays, and claystone to dusty claystone of brown to grey-brown colour. It is fine-grained, and its mineralogic complexion is dominated by quartz, caolinite, and illite. They have very good chemic-pedologic qualities. Their sorption abilities can be marked as medium. They can be immediately used for forest reclamation; a systematic areal compost application is recommended.

\subsubsection{Overlying Montmorillonite Claystone of the Libous Mine}

They appear at the top horizon of the tertiary level under yellow clays. This rock type consists mainly of clays, and claystone to dusty claystone of brown, yellow-brown to grey-brown colour. It is fine-grained, and its mineralogic complexion is dominated by quartz, montmorillonite, caolinite, illite, and traces of feldspar. They have very good chemical-pedologic qualities. Their sorption 
abilities can be described as excellent. They can be immediately used for forest reclamation. A compost or industry fertiliser application to single plants is recommended.

\subsubsection{Bentonites}

The only significant deposits of bentonite in the North Bohemian Basin are concentrated in the vicinity of Branany village (Cerný vrch hill locality) and in Kadan town (Rokle locality). Bentonites can be defined as montmorillonite claystone. It is fine-grained, with its mineralogic complexion dominated by montmorillonite; caolinite and quartz are normal ingredients, with some traces of illite, siderite, and feldspar. They have excellent chemical and pedological qualities and very high sorption ability, and their reclamation utility is excellent. Application in large reclamation actions is limited by its economic demands.

\subsection{Characteristics of the Main Localities of the Bentonites in the Most Basin}

\subsubsection{Cerny vrch Bentonite Locality}

The Cerny vrch bentonite locality can be found about $1 \mathrm{~km}$ from classic recently mined Branany deposit. Together with Rokle near Kadan town, they are the most significant deposits in the Most Basin today. The locality is bound to the vulcanodetritic strata of the coal seam subjacent bed. It consists mainly of clayed tuffs; a marginal eroded vulcanic rock was the mother rock. High quality blue to blue-green betonite occurs in the deposit (especially in its base). Most of the deposit consists of yellow-green to yellow-brown bentonite. The raw material can be used as bleaching clay (the best quality bentonite) and foundry purposes; recently it has also been used in the production of cat litter. The Cerný vrch deposit verges into the Strimice deposit, and the mined locality is usually referred to as Cerný vrch by the owner (Keramost, j.s.c.). The mined bentonites consist of montmorillonite, with the main ingredients being caolinite, siderite, illite. Quartz can also occur in a lower rate. The situation in the locality is shown in Figure 1.

The second most important bentonite deposit, in Rokle is about $3 \mathrm{~km}$ south at Kadan town near the slopes of the Doupov Mountains (Figure 2).

The locality is linked to the tertiary vulcanodetritic strata of the coal seam subjacent bed. It consists of sandy tuffitic tuffs. All the pyroclastic material except biotite is totaly dispersed in the clayey mass. Most of the deposit consists of yellow-green to yellow-brown bentonite. The raw material can mainly be used for foundry purposes. A horizon of caolinic sands, approximately 5 to $10 \mathrm{~m}$ high, can be found under the bentonite horizon, approximately $30 \mathrm{~m}$ high; these are also mined as raw kaoline. The mined bentonite consists of a mixture of the prevailing montmorillonite and caolinite, with the main ingredients being siderite, illite and quarty. The raw material is of a slightly lower quality than that in the Cerný vrch locality. The quality of the bentonites in the Cerný vrch and Rokle localities is shown in Table 1. 


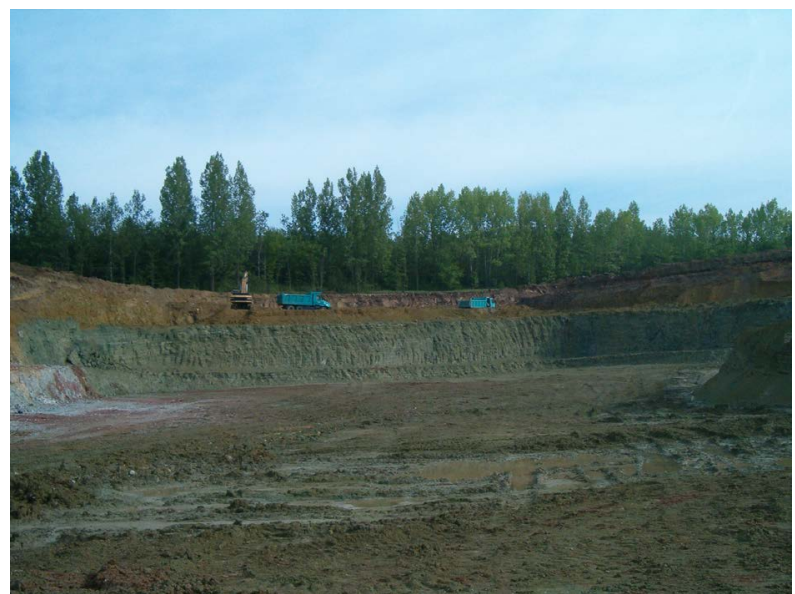

Figure 1. Bentonite doposit No.1 in Rokle [8].

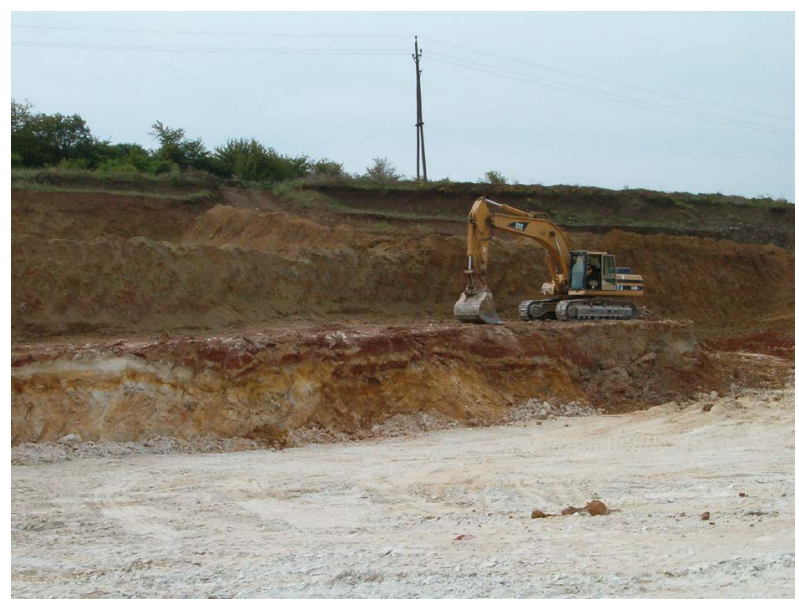

Figure 2. Bentonite deposit No. 2 in Rokle [8].

Table 1. Properties of bentonites samples [9].

\begin{tabular}{|c|c|c|c|c|c|c|c|c|c|c|}
\hline \multirow{2}{*}{$\begin{array}{c}\text { locality of } \\
\text { bentonite } \\
\text { sample }\end{array}$} & \multirow{2}{*}{ N (\%) } & \multirow{2}{*}{$\operatorname{Cox}(\%)$} & \multirow{2}{*}{$\begin{array}{c}\mathrm{CaCO}_{3} \\
(\%)\end{array}$} & \multirow{2}{*}{$\mathrm{pH} / \mathrm{H}_{2} \mathrm{O}$} & \multicolumn{3}{|c|}{$\begin{array}{c}\text { Receivable } \\
\text { nutrients }\left(\mathrm{mg} \cdot \mathrm{kg}^{-1}\right)\end{array}$} & \multicolumn{3}{|c|}{$\begin{array}{c}\text { Absorbtion } \\
\text { Capacity mmol (\%) }\end{array}$} \\
\hline & & & & & $\mathbf{P}$ & $\mathrm{K}$ & $\mathrm{Mg}$ & $S$ & $\mathrm{~T}$ & $\mathrm{~V}$ \\
\hline Cerny vrch & 0.05 & 0.53 & 8.86 & 8.31 & 2 & 321 & 998 & 38 & 38 & 100 \\
\hline Rokle & 0.05 & 1.07 & 5.65 & 7.99 & 1 & 288 & 876 & 24 & 24 & 100 \\
\hline
\end{tabular}

\subsubsection{Strimice Dump Reclamation-An Example of the Application of Bentonite}

Dump (spoil tip) is an anthropogenic formation made of overburden soil that cover coal seam. The Strimice dump is located near the town of Most. It had been formed since 1959 to 1973 and its elevation point reached 330 meters above sea level. Bentonite rocks that were mined in Cerny vrch were used for creation of a $50 \mathrm{~cm}$ thick surface layer. After the ploughing, grass and trees were planted on the dump. 89 ha of the dump surface were then used for agricultural reclamation [10]. The newly created soil profile is divided into an upper layer consisting of mixture of topsoil and bentonite, a middle layer consisting of mixture 
Table 2. Properties of the soil profile reclaimed with bentonites.

\begin{tabular}{ccccccccccc}
\hline $\begin{array}{c}\text { Probe } \\
\begin{array}{c}\text { S1-sample } \\
\text { taking interval } \\
(\mathrm{m})\end{array}\end{array}$ & $\mathrm{N}$ & $\mathrm{Cox}$ & $\mathrm{CaCO}_{3}$ & $\mathrm{pH} / \mathrm{H}_{2} \mathrm{O}$ & $\begin{array}{c}\text { Receivable nutrients } \\
\left(\mathrm{mg}^{\left.-\mathrm{kg}^{-1}\right)}\right.\end{array}$ & \multicolumn{3}{c}{$\begin{array}{c}\text { Absorbtion } \\
\text { Capacity mmol (\%) }\end{array}$} \\
\hline & $(\%)$ & $(\%)$ & $(\%)$ & & $\mathrm{P}$ & $\mathrm{K}$ & $\mathrm{Mg}$ & $\mathrm{S}$ & $\mathrm{T}$ & $\mathrm{V}$ \\
\hline $0.00-0.60$ & 0.07 & 1.24 & 0.98 & 6.79 & 10 & 190 & 102 & 13.4 & 19.7 & 68 \\
$0.60-0.90$ & 0.07 & 0.68 & 9.93 & 8.23 & 1 & 218 & 949 & 36.3 & 36.3 & 100 \\
Under 0.90 & 0.15 & 2.94 & 0.24 & 4.50 & 1 & 103 & 304 & 3.1 & 8.2 & 39 \\
\hline
\end{tabular}

of clay and bentonite and the original material in the dump. Mineralogy of upper layer is defined by quartz, kaolinite, illite, and montmorillonite with a mixture of spars and muscovite. The chemical status of the upper relatively favourable with neutral soil reaction, medium content of humus, low content of nitrogen and phosphorus, and medium to high content of magnesium and potassium. The soil is quite coarse, and sandy to loamy, therefore it is suitable for reclamation. The middle layer contains larger amount of montmorillonite. The soil reaction is lightly alkaline with increasing calcite content. The nitrogen and humus content is low. Middle layer is a bit higher on nutrients than the upper layer. This soil is not suitable for reclamation, because it contains yellow clay with pieces of coal. The results shown in Table 2 confirm successful reclamation of the Strrimice dump thanks to the chosen method.

\section{Conclusion}

The potential deposits of claystone sorbents in the North Bohemian Basin will be found and evaluated in the frame of the recently commenced research works. These rocks would otherwise end up in mine dumps, but nevertheless they may sometimes be raw materials with exceptional qualities. A suitable application of claystone sorbents will make the technical restoration in the North Bohemian Basin more effective and it can also be used in the sanitation of the old ecologic burdens in the Czech Republic (especially in the cases of involving contaminated mine waters). The kaolinite-illite claystone of the Libkovice strata, motnorillonite claystones and bentonites were tipped as potential claystone sorbents in the first stage of the mapping works. The occurrence of these rocks, their brief characteristics, and their application possibilities in the reclamation are described in the article. The experiences from the single large application of claystone sorbent in the Strimice dump so far are also set out here.

\section{Acknowledgements}

This article was supported by project QJ1520307 entitled "Sustainable Forms of Management in an Anthropogenically Burdened Region". This project was realized with financial support from state budget resources through the KUS program, Ministry of Agriculture of the Czech Republic. 


\section{References}

[1] Murray, H.H. (2007) Applied Clay Mineralogy. Indiana University, Indiana, Elsevier, $179 \mathrm{p}$.

[2] Hermosin, M., Martin, P. and Cornej, J. (1993) Adsorption Mechanisms of Monobutyltin in Clay Minerals. Environmental Science \& Technology, 27, 2606-2611. https://doi.org/10.1021/es00048a044

[3] Egloffstein, T.A. (2001) Natural Bentonites-Influence of the Ion Exchange and Partial Desiccation on Permeability and Self-Healing Capacity of Bentonites Used in GCLs. Geotextiles and Geomembranes, 19, 427-444. https://doi.org/10.1016/S0266-1144(01)00017-6

[4] Karnland, O., Olsson, S. and Nilsson, U. (2006) Mineralogy and Sealing Properties of Various Bentonites and Smectite-Rich Clay Materials. Technical Report TR-06-30. Clay Technology AB, Stockholm, $112 \mathrm{p}$.

[5] Cermák, P. (1998) Methodical Bases for Evaluation of the Anti-Erosion Resistance of Dump Soil with Vegetation or Other Preparation in SHP. Research Report, Institute of Soil Improvement and Soil Protection, Prague, 9 p.

[6] Fisera, E. (1990) Evaluation of Soil in the North Bohemian Basin in Terms of Suitability. Research Report, Mining Projects of Teplice, 15 p.

[7] Hrasko, T. and Bedrna, J. (1988) Applied Soil Science. Nature, 1. Edition, Bratislava, $474 \mathrm{p}$.

[8] Řehoř, M. (2006) Author's Own Photo Documentation. Photo Archive of Research Institute for Brown Coal in Most.

[9] Řehoř, M., et al. (2002) Use of Accessory Material Acquired in Opencast Mining of Brown Coal Deposits for Reclamation of These Sites. Abstract, Mining University in Ostrava.

[10] Rehor, M. (1999) Research of the Suitability of Overburden Soil for Restoration Purpose. Expert Review, Research Institute for Brown Coal in Most. 